\title{
Pengembangan Buku Ajar pada Materi Pengukuran Panjang Kelas IV dengan Pendekatan Open Ended untuk Meningkatkan Kemampuan Penalaran Siswa di SD Kota Semarang
}

\section{Ulya Izza Rahayu}

Program Studi Pendidikan Guru Sekolah Dasar; Fakutas Ilmu Pendidikan Universitas PGRI Semarang; Jl. Sidodadi Timur Nomor 24-Dr. Cipto SemarangIndonesia; ulyaiza0214@gmail.com

\begin{abstract}
Abstrak. Penelitian ini dilatarbelakangi oleh buku ajar yang kurang detail, kurang latihan soal dan pembahasannya, serta pengembangan materi yang kurang luas terutama pada materi pengukuran panjang di SD Kota Semarang. Tujuan utama penelitian ini untuk mengembankan perangkat pembelajaran dengan menggunakan pendekatan open ended yang baik (valid, aktif, dan efektif) untuk meningkatkan kemampuan penalaran matematika siswa. Buku ajar yang dikembangkan berupa buku ajar pada materi pengukuran panjang kelas IV Sekolah Dasar. Metode yang digunakan dalam penelitian ini adalah metode penelitian dan pengembangan. Prosedur penelitian menggunakan pendekatan Borg and Gall, dengan memodifikasi langkah-langkah penelitian menjadi : tahap potensi masalah, tahap desain produk, tahap validasi produk, tahap instrumen uji coba, tahap uji coba terbatas. Rata-rata keseluruhan hasil validasi yaitu 4,27. Persentase kenaikan hasil pretest dan posttest sebesar 25,7 \%. Maka buku ajar masuk dalam kategori baik, valid dan efektif dalam meningkatkan penalaran siswa.
\end{abstract}

Kata kunci: Buku ajar, Open Ended, Penalaran.

Abstract. This research is motivated by the lack of detailed textbooks, lack of practice questions and discussion, as well as the development of material that is less extensive, especially on length measurement material in Elementary School Semarang City. The main objective of this study is to develop learning tools using a good open ended approach (valid, active, and effective) to improve students' mathematical reasoning abilities. The textbook developed was in the form of a textbook on the material for length measurement of grade IV elementary school. The method used in this research ismethods research and development. Theprocedure researchuses theapproach Borg and Gall, by modifying the research steps into: the potential problem stage, the product design stage, the product validation stage, the trial instrument stage, the limited trial phase. The overall average of validation results is 4.27. The percentage increase in pretest and posttest results was $25.7 \%$. Then the textbooks fall into the category of good, valid and effective in improving student reasoning.

Keywords: Textbooks, Open Ended, Reasoning.

Caruban: Jurnal Ilmiah Pendidikan Dasar 3(1), 29-39, Januari 2020

DOI: http://dx.doi.org/10.33603/.v3i1.3046, p-ISSN 2615-1391, e-ISSN 2620-3219

CProdi PGSD Universitas Swadaya Gunung Jati 


\section{Pendahuluan}

Pendidikan merupakan salah satu faktor yang dapat menentukan kualitas SDM suatu bangsa terutama dalam menghadapi kemajuan teknologi dan tantangan zaman. Oleh karena itu, perancangan dan perkembangan pembelajaran harus sesuai dengan perkembangan IPTEK. Saat ini bangsa Indonesia telah memasuki pendidikan abad 21. Implikasinya dalam bidang pendidikan menuntut masyarakat dunia untuk menguasai keterampilan abad 21 yaitu mampu memahami dan memanfaatkan teknologi informasi dan komunikasi (ICT Literacy Skills). Beberapa keterampilan yang harus dikuasai generasi abad 21 yaitu (1) keterampilan belajar dan inovasi meliputi berpikir kritis dan pemecahan masalah dalam komunikasi dan kreativitas kolaboratif dan inovatif, (2) keahlian literasi digital meliputi literasi media baru dan literasi ICT, (3) kecakapan hidup dan karier meliputi memiliki kemampuan inisiatif yang fleksibel dan inisiatif adaptif, dan kecakapan diri secara sosial dalam interaksi antar budaya, kecakapan kepemimpinan produktif dan akuntebel, serta bertanggungjawab (Sulianto, 2019:397). Berdasarkan kriteria tersebut peserta didik dituntuntut untuk memiliki keterampilan belajar inovatif dan kretif hal itu sesuai dengan Permendikbud Nomor 21 Tahun 2016 yaitu tujuan pendidikan di Indonesia adalah untuk mengembangkan kemampuan dan potensi peserta didik agar memiliki pribadi yang berilmu, kreatif, serta mandiri.

Saat ini, dengan berlakunya kurikulum 2013 diharapkan dapat membentuk peserta didik yang aktif dan kreatif dalam ranah kognitif atau ilmu pengetahuan pada suatu pembelajaran yang sedang berlangsung (Kemendikbud, 2014) dalam Apertha (2018:48). Namun Yusuf (2009: 3) menyatakan bahwa pembelajaran matematika selama ini menekankan pada hapalan dan mencari satu jawaban yang benar untuk soal-soal yang diberikan sehingga proses berfikir peserta didik di sekolah masih jarang dilatih. Seperti yang diungkapkan oleh Aryanti (2014) dalam Apertha (2018:48) Hal ini dapat dilihat dari buku pelajaran matematika yang digunakan peserta didik, kebanyakan soal-soal yang ada hanya memiliki satu jawaban yang benar atau kovergen. Hal tersebut menyebabkan kesempatan siswa untuk berpikir dengan bebas sesuai minat dan kemampuanya terbatas. siswapun tidak maksimal dalam memperoleh pengetahuan atau pengalaman menemukan, mengenali, dan memecahkan

Caruban: Jurnal Ilmiah Pendidikan Dasar 3(1), 29-39, Januari 2020

DOI: http://dx.doi.org/10.33603/.v3i1.3046, p-ISSN 2615-1391, e-ISSN 2620-3219

CProdi PGSD Universitas Swadaya Gunung Jati 
masalah dengan beragam teknik. Dalam proses menemukan jawaban yang divergen itulah dibutuhkan kegiatan-kegiatan yang dapat menjadikan peserta didik untuk berfikir dengan bernalar. Selain itu berdasarkan observasi peneliti ke beberapa guru sekolah dasar di Kota Semarang terutama guru kelas IV melalui pembagian angket diperoleh hasil pembelajaran matematika memerlukan buku ajar yang lebih detail, banyak latihan soal dan pembahasannya, serta pengembangan materi yang lebih luas terutamapada materi pengukuran panjang.

Salah satu pembelajaran yang dapat mengembangkan kemapuan berfikir peserta didik adalah pembelajaran matematika berbasis open-ended problem (Yuliana, 2015) dalam Apertha (2018:48). Untuk mendapatkan kemampuan berpikir perlu didukung kemampuan penalaran yang baik, maka pembelajaran berbasis open ended ini juga dapat mengembangkan kemampuan bernalar siswa. Pendekatan open ended (Astin, \& Bharata, 2016) dalam Mayasari (2019:100) adalah pendekatan yang memberikan suatu masalah dengan banyak cara penyelesaian dan banyak jawaban. Menurut Becker dan Shimida (1997) dalam Apertha (2018:48) pendekatan open-ended problem adalah pendekatan pembelajaran yang mengandung potensi yang sangat besar untuk meningkatkan kualitas pembelajaran matematika dengan menyajikan suatu permasalahan yang memiliki metode atau penyelesaian benar lebih dari satu macam. Maka open ended juga bisa dikatakan sebagai pendekatan dengan menyajikan masalah terbuka dengan penyelesaian lebih dari satu cara yang benar.

Aspek keterbukaan (Uhti, 2011) dalam Mayasari (2019:101) mengataka bahwa dalam soal terbuka dapat diklasifikasikan ke dalam tiga tipe yaitu: 1) terbuka proses penyelesaiannya yakni masalah memiliki beragam cara penyelesaian, 2) terbuka hasil akhirnya, yakni soal tersebut memiliki banyak jawaban yang benar, 3) pengembangan lanjutannya, yakni ketika siswa telah menyelesaikan sesuatu, selanjutnya mereka dapat mengembangkan soal baru dengan mengubah syarat atau kondisi pada soal yang telah diselesaikan. Dengan menggunakan pendekatan ini diharapkan kemampuan penalaran matematis siswa dapat meningkat. Penalaran adalah proses berpikir yang logis dan sistematis atas fakta-kata empiris yang dapat diobservasi untuk memperoleh simpulan berupa pengetahuan

Caruban: Jurnal Ilmiah Pendidikan Dasar 3(1), 29-39, Januari 2020

DOI: http://dx.doi.org/10.33603/.v3i1.3046, p-ISSN 2615-1391, e-ISSN 2620-3219

CProdi PGSD Universitas Swadaya Gunung Jati 
(Kemendikbud, 2015: 140). Penalaran merupakan kegiatan berpikir dalam mengembangkan argumentasi untuk meyakinkan orang lain atas pernyataan tertentu atau dalam menyelesaikan masalah atau untuk mengintegrasikan ide dalam pemecahan masalah (Brodie, 2010: 14) dalam Sulianto (2019:398) . Sulianto (2019:398) dalam penelitianya menyatakan bahwa penalaran adalah kegiatan menghubungkan fakta-fakta atau proses berfikir dalam mengembangkan argumentasi untuk menarik kesimpulan atau memberikan jawaban dalam pemecahan masalah. Jadi dapat sidimpulkan penalaran dalam penelitian ini adalah aktivitas berpikir yang logis dan sistematis untuk mengintegrasikan ide dalam pemecahan masalah untuk menarik kesimpulan atau membuat suatu pernyataan baru yang benar berdasarkan pada beberapa pernyataan yang kebenarannya telah dibuktikan atau diasumsikan sebelumnya.

Pengembangan buku ajar berbasis open ended berorientasi mengembangkan kemampuan bernalar siswa sejalan dengan penelitian penerpan model berbasis open ended yang dilakukan oleh Joko Sulianto, Sunardi, Sri Anitah, Gunarhadi pada tahun 2019 yang hasilnya menyatakan penggunakan pendekatan open ended mampu meningkatkan kemampuan penalaran siswa. Selain itu juga sejalan dengan penelitian yang dilakukan oleh Dian Mayasari, 2019 yang menyatakan pengemangan buku ajar berbasis open ended valid dan efektif dalam meningkatkan kemampuan siswa memecahkan masalah, maka hal itu juga menunjukkan kemampuan bernalar siswa meningkat dan berjalan dengan baik.

Berdasarkan latar belakang tersebut maka peneliti bermaksud mengembangkan buku ajar pada materi pengukuran panjang kelas IV SD berbasis pendekatan open ended yang bertujuan untuk meningkatkan kemampuan penalaran siswa di SD Kota Semarang. Buku ajar yang dikembangkan ini berupa buku ajar yang berorientasi memberikan kesempatan kepada peserta didik untuk menerapkan ide-ide sendiri dengan memilih dan menggunakan beberapa strategi, metode maupun teknik yang dapat menjadikan peserta didik aktif dan berfikir dalam proses pembelajaran, hal itu juga berbanding lurus dengan kemampuan bernalar siswa karena untuk menentukan strategi dalam penyelesaian masalah terebut membutuhkan kemampuan penalaran yang baik. Dengan demikian

Caruban: Jurnal Ilmiah Pendidikan Dasar 3(1), 29-39, Januari 2020

DOI: http://dx.doi.org/10.33603/.v3i1.3046, p-ISSN 2615-1391, e-ISSN 2620-3219

CProdi PGSD Universitas Swadaya Gunung Jati 
penelitian ini sangat berpotensi untuk meningkatkan kemampuan penalaran siswa sekolah dasar di Kota Semarang.

\section{Metode}

Penelitian ini dilaksanakan dengan pendekatan penelitian dan pengembangan atau Research and Development. Penelitian pengembangan ini adalah penelitian yang ditujukan untuk menghasilkan buku ajar matematika dengan pendekatan Opend Ended pada materi pengukuran panjang kelas IV Sekolah Dasar. Tempat penelitian ini adalah 3 SD di Kota Semarang yaitu SD N Pandean Lamper 05, SD N Bugangan 03, dan SD N Bugangan 03. Sumber data diperoleh dari guru dan siswa melalui penyebaran angket, observasi, dan hasil uji coba/tes.

Prosedur pengembangan buku ajar yang digunakan yaitu pendekatan Borg and Gall, Peneliti memodifikasi langkah-langkah penelitian dan pengembangan menurut Borg and Gall (dalam Sugiyono, 2015 : 35) yang terdiri dari : tahap potensi masalah, tahap desain produk, tahap validasi produk, tahap instrumen uji coba, tahap uji coba terbatas. Teknik pengumpulan data yang digunakan dalam penelitian ini adalah teknik Pengumpulan Data pada Penelitian dan Pengembangan Level 3 untuk mengembangkan produk yang telah ada (Sugiyono, 2015:203) terdapat 6 kegiatan pengumpulan data yaitu : tahap 1 dilakukan untuk memperoleh data terhadap produk yang ada, baik aspek bentuk performance maupun spesifikasi kerjanya; tahap 2 untuk mengetahui apakah produk tersebut sesuai dengan kebutuhan lapangan atau tidak; tahap 3 untuk memperoleh data hasil pengujian internal yang dilakukan oleh ahli dan praktisi terhadap rancangan/ desain baru yang telah dibuat; tahap 4 pengumpulan data untuk memperoleh data dari hasil uji coba lapangan terbatas ( preliminary field testing ); tahap 5 pengumpulan data untuk memperoleh data hasil uji coba lapangan utama ( main field testing ) dan tahap 6 yaitu uji coba lapagan operasional ( operational field testing ). Uji coba lapangan utama ( main field testing ) dan uji coba lapagan operasional ( operational field testing ) pada penelitian ini tidak dilakukan mengingat waktu dan dana yang tersedia terbatas. Dalam melaksanakan tahapan tersebut menggunkan teknik tes dan non tes. Intrumen yang digunakan berupa angket, observasi, uji ahli

Caruban: Jurnal Ilmiah Pendidikan Dasar 3(1), 29-39, Januari 2020

DOI: http://dx.doi.org/10.33603/.v3i1.3046, p-ISSN 2615-1391, e-ISSN 2620-3219

CProdi PGSD Universitas Swadaya Gunung Jati 
(kesioner validitas buku) dan tes hasil belajar ( pre-test dan post-test ) dengan menggunakan buku ajar opend ended .

Teknik analisis data dalam penelitian ini menggunakan teknik Analisis Data RnD Level 3 (Sugiyono, 2015: 248). Teknik analisis ini dilakukan dengan cara menganalisis hasil dari setiap tahap pengumpulan data, karena tahap pengumpulan data ada 6 tetapi hanya sampai tahap 4 maka teknik analisis data ada 4 juga antara lain: tahap 1 analisis terhadap data yang diperoleh dari penelitian terhadap produk yang ada; tahap 2 analisis data hasil penelitian lapangan untuk mengetahui apakah produk tersebut sesuai kebutuhan lapangan atau tidak; tahap 3 analisis data hasil pengujian internal yang dilakukan oleh ahli dan praktisis terhadap rancangan baru yang telah dibuat; tahap 4 analisis terhadap data hasil uji coba lapangan awal/ terbatas.

\section{Hasil dan Pembahasan}

Penelitian ini menghasilkan buku ajar matematika berbais open ended yang valid, praktis serta efektif terhadap kemampuan penalaran siswa pada materi pengukuran panjang kelas IV di SD Kota Semarang.

\section{Proses Pengembangan Buku Ajar}

Pada tahap pertama penelitian mencari potensi dan masalah melalui angket. Angket diberikan kepada 3 guru di masing-masing SD di Kota Semarang. Penyebaran angket bertujuan untuk memperoleh informasi mengenai kebutuhan lapangan, kesulitan yang dihadapi guru mengenai materi pegukuran panjang, buku ajar yang diharapkan guru, dan pendapat guru mengenai adanya rencana pengembangan buku berbasis open-ended. Hasilnya sebagi berikut bahwa buku ajar matematika yang digunakan belum mencukupi sebagai sumber belajar karena latihan soalnya kurang dan pengembangan materi kurang dalam, perlu adanya buku ajar dengan materi pengukuran panjang yang memberi kesempatan siswa untuk berpikir dengan bebas sesuai dengan minat dan kemampuannya, perlu adanya buku ajar yang memberikan kesempatan kepada siswa untuk memperoleh pengetahuan/pengalaman menemukan, mengenali, dan memecahkan masalah dengan beragam teknik, perlu adanya buku ajar matematika dengan materi pengukuran panjang yang penuh dengan ide-ide mtematika untuk memacu kemampuan penalaran siswa.

Caruban: Jurnal Ilmiah Pendidikan Dasar 3(1), 29-39, Januari 2020

DOI: http://dx.doi.org/10.33603/.v3i1.3046, p-ISSN 2615-1391, e-ISSN 2620-3219

CProdi PGSD Universitas Swadaya Gunung Jati 
Tahap kedua desain produk, dengan menentukan KI dan KD lalu mencari sumber belajar berupa materi dan gambar-gambar yang akan digunakan untuk produk buku. Kompetensi Dasar yang digunakan yaitu 3.7 Menjelaskan dan melakukan pembulatan hasil pengukuran panjang kesatuan terdekat dan 4.7 menyelesaikan masalah pembulatan hasil pengukuran panjang ke satuan terdekat. Cover dibuat dengan warna dan gambar yang menarik, lalu ada kata pengantar, petujuk penggunaan buku, daftar isi, isi materi, latihan-latihan.

Tahap ketiga yaitu validasi, produk dalam penelitian ini validasi produk dilakukan oleh dua validtor ahli yaitu validasi ahli pembelajaran openended 1 yang dilakukan oleh dosen Matematika dan validasi ahli pembelajaran open-ended 2 yang dilakukan oleh guru SD. Rentan skor yang digunakan terdiri dari 5 skala untuk pengkonversian data. Pengkonversian tersebut mengacu pada skala Likert (Widyoko, 2013:144). Berdasarkan perhitungan skala Likert tersebut, diperoleh konversi data kuantitatif menjadi data kualitatif skala lima seperti pada tabel 1 berikut:

Tabel 1. Kriteria Skala Lima

\begin{tabular}{cc}
\hline Interval Skor & Kriteria \\
\hline$x>4,21$ & Sangat baik \\
$3,40<x \leq 4,21$ & Baik \\
$2,60<x \leq 3,40$ & Cukup \\
$1,79<x \leq 2,60$ & Kurang \\
$X \leq 1,79$ & Sangat Kurang \\
\hline
\end{tabular}

Setelah melakukan uji ahli peneliti mendapatkan analisis 1 yang kemudian dijadikan acuan untuk melakukan revisi. Hasil validasi ahli yang diperoleh seperti pada tabel 2 berikut ini.

Tabel 2. Nilai Rata-rata Hasil Validasi

Rata-rata

Kriteria Hasil

Validasi

Ahli 1 Ahli 2

$\begin{array}{lllll}\text { Nilai rata- } & \text { Tujuan dan pendekatan } & 4 & 4,5 & \text { Baik }\end{array}$

Caruban: Jurnal Ilmiah Pendidikan Dasar 3(1), 29-39, Januari 2020

DOI: http://dx.doi.org/10.33603/.v3i1.3046, p-ISSN 2615-1391, e-ISSN 2620-3219

CProdi PGSD Universitas Swadaya Gunung Jati 
Rata-rata

Kriteria Hasil

Validasi

Ahli 1 Ahli 2

\begin{tabular}{lllll}
\hline rata & $\begin{array}{l}\text { yang digunkan dalam } \\
\text { penyusunan buku open ended }\end{array}$ & & & \\
Cover & 4 & 4,67 & Baik \\
Isi buku & 4,2 & 4,8 & Baik \\
Bahasa & 4 & 4 & Baik \\
Gambar & 4,25 & 4,25 & Baik \\
Rerata total & 4,09 & 4,45 & Baik \\
\hline
\end{tabular}

Berdasarkan semua aspek, rerata total dari validator satu adalah 4,09 dan rerata total dari valiator 2 adalah 4,45. Rerata total dari masing-masing ahli kemudian diakumulasikan untuk mendapat Rerata total secara keseluruhan. Diperoleh rerata keseluruhannya yaitu 4,27. Maka buku ajar masuk dalam kategori sangat baik dan layak diujikan.

Tahap keempat instrumen penelitian, instrumen yang digunakan dalam penelitian ini adalah tes. Tes awal dilakukan dengan melakukan uji empiris di kelas IV. Hasil dari tes uji empiris digunakan untuk mengetahui validitas dan realibilitas soal tersebut yang nantinya digunakan sebagai soal pretest dan posttest. Nilai pretest diambil sebelum uji coba terbatas dan nilai posttest diambil setelah uji coba terbatas dilakukan. Soal yang digunakan peneliti untuk menguji pretest dan posttest adalah 20 soal. Soal pretest dan posttest disesuaikan yaitu menggunkan soal penalaran yang berfungsi untuk mengetahui keefektifan buku tersebut terhadap kemampuan penalaran siswa. Tahap selanjutnya dijelaskan pada bagian uji lapangan

\section{Uji Lapangan Menghasilkan Pembelajaran yang Efektif}

UJi lapangan masuk kedalam tahap kelima yaitu uji coba terbatas, setelah produk direvisi peneliti melakukan ujicoba terbatas yang dilakukan di SD Pandean Lamper 05 Semarang. Uji coba terbatas dilaksanakan di kelas IV A yang berjumlah 30 siswa, namun peneliti hanya mengambil 5 siswa yang digunakan sebagai sampel uji coba. Tahap uji coba pertama peneliti melakukan pretest. Pretest digunakan untuk mengetahui kemampuan awal

Caruban: Jurnal Ilmiah Pendidikan Dasar 3(1), 29-39, Januari 2020

DOI: http://dx.doi.org/10.33603/.v3i1.3046, p-ISSN 2615-1391, e-ISSN 2620-3219

CProdi PGSD Universitas Swadaya Gunung Jati 
siswa. Setelah selesai melakukan uji coba produk kemudian menguji soal posttest. Posttest dilakukan untuk mengetahui kemampuan siswa setelah diberikan perlakuan dengan produk. Nilai yang didapatkan diperoleh dari skor jawaban siswa. Di bawah ini adalah rumus yang digunakan untuk perhitungan pretest dan posttest.

(1) Rumus Nilai Tes.

$$
\text { Nilai tes }=\frac{\text { Jumlah skor yang didapat }}{\text { Skor maksimal }} \times 100
$$

Nilai sampel dari data pretest dan posttest uji coba dapat dilihat pada tabel 3 berikut :

Tabel 3. Data pretest dan posttest

\begin{tabular}{|c|c|c|c|c|}
\hline \multirow{2}{*}{ Nama } & \multicolumn{2}{|c|}{ Pretest } & \multicolumn{2}{|c|}{ Posttest } \\
\hline & Skor & Nilai & Skor & Nilai \\
\hline $\mathrm{A}$ & 10 & 50 & 16 & 80 \\
\hline B & 15 & 75 & 17 & 85 \\
\hline C & 16 & 80 & 19 & 95 \\
\hline $\mathrm{D}$ & 16 & 80 & 20 & 100 \\
\hline $\mathrm{E}$ & 13 & 65 & 18 & 80 \\
\hline Total nilai & \multicolumn{2}{|c|}{350} & \multicolumn{2}{|c|}{440} \\
\hline Rarata nilai & \multicolumn{2}{|c|}{70} & \multicolumn{2}{|c|}{88} \\
\hline Peningkatan & \multicolumn{4}{|c|}{18} \\
\hline Persentase & \multicolumn{4}{|c|}{$25,7 \%$} \\
\hline
\end{tabular}

Dari data di atas, dapat dilihat bahwa terjadi peningkatan nilai siswa dari pretest ke posttest. A mengalami peningkatan dari 50 menjadi 80, nilai B menglami peningkatan dari 75 menjadi 85, dst. Sehingga diperoleh rata-rata nilai pretest adalah 70 sedangkan rata-rata nilai posttest adalah 88 . Peningkatan hasil dari pretest ke posttes adalah 18, Sehingga persentase kenaikannya adalah 25,7 \%. Berdasarkan hasil analisis nilai pretest dan posttest tersebut maka diketahui bahwa buku ajar matematika yang digunakan pada pembelajaran matematika materi pengukuran panjang memiliki dampak yang baik dan efektif terhadap kemampuan penalaran siswa.

Caruban: Jurnal Ilmiah Pendidikan Dasar 3(1), 29-39, Januari 2020

DOI: http://dx.doi.org/10.33603/.v3i1.3046, p-ISSN 2615-1391, e-ISSN 2620-3219

CProdi PGSD Universitas Swadaya Gunung Jati 


\section{Simpulan dan Rekomendasi}

Dari hasil penelitian dapat disimpulkan bahwa buku ajar yang dikembangkan dengan pendekatan open ended untuk meningkatkan kemampuan penalaran siswa adalah valid, praktis, dan efektif. Dilihat dari hasil rerata total validator satu yaitu 4,09 dan rerata total dari valiator 2 sebesar 4,45. Rerata total dari masing-masing ahli kemudian diakumulasikan untuk mendapat Rerata total secara keseluruhan. Diperoleh rerata keseluruhannya yaitu 4,27. Maka buku ajar masuk dalam kategori baik dan valid. Kemampuan penalaran siswa pada pembelajaran matematika menggunakan buku ajar berbasis pendekatan open ended mengalami peningkatan dari nilai pretest ke nilai posttest. Peningkatan terlihat dari ratarata nilai pretest sebesar 70 sedangkan rata-rata nilai posttest mencapai 88 . Peningkatan hasil dari pretest ke posttes adalah 18, Sehingga persentase kenaikannya adalah 25,7 \%. Berdasarkan hasil analisis nilai pretest dan posttest tersebut maka buku ajar matematika berbasis open ended yang digunakan pada pembelajaran matematika materi pengukuran panjang memiliki dampak yang baik dan efektif terhadap kemampuan penalaran siswa.

Rekomendasi yang diberikan 1) Pada penelitin selanjutnya, peneliti dapat menggunakan kesepuluh langkah Borg and Gall agar produk yang dihasilkan dapat diproduksi secara masal dengan kualitas produk yang lebih baik lagi. 2) Proses persiapan media harus lebih dikontrol dan dipersiapkan jauh-jauh hari agar yang sudah direncanakan dapat terlaksana dengan maksimal.

\section{Daftar Pustaka}

Apertha, Fanny Khairul Putri, Zulkardi, Muhamad Yusup. (2018). Pengembangan LKPD Berbasis Open-Ended Problem pada Materi Segiempat Kelas VII. Jurnal Pendidikan Matematika Vol.12 (2), 47-62.

Arifania, Devina Anky. (2017). Pengembangan Buku Guru dan Buku Siswa Matematika kelas I Sekolah Dasar Dengan Pendekatan Pendidikan Matematika Realistik Indonesia [Skripsi]. Yogykarta (ID): Univesitas Sanata Darma.

Erman Suherman. (2001). Strategi Pembelajaran Matematika Kontemporer. Bandung: JICA-UPI. 
Mayasari, Dian. (2019). Pengembangan Bahan Ajar Segitiga Dengan Pendekatan Open Ended Untuk Meningkatkan Kemampuan Pemecahan Masalah Matematika. Jurnal Inovasi Matematika (Inomatika) Vol. 1 (2) , 99-109.

Nashihah, Durrotun., Joko Sulianto, Mei Fita Asri Untari. (2019). Klasifikasi Kemampuan Penalaran Matematis Siswa Kelas IV SD Negeri Tambakrejo 02 Semarang. Indonesian Journal Of Educational Research and Review Vol.2 (2), 203-209.

Sugiyono.(2015).Metode Penelitian dan Pengembangan (Research and Development) Bandung:s Alfabeta

Sulianto, Joko, Sunardi, Sri Anitah, Gunarhadi.(2019). Analisis Implementasi Pembelajaran di Sekolah Dasar pada Pengembangan Model Advance Organizer berbasis Pendekatan Open Ended untuk Meningkatkan Penalaran Siswa. International Journal of Elementary Education Vol.3 (4), 396-403.

Widiyasari, R. (2015). Pengembangan Pembelajaran Matematika Konstruktivis Berbantu E-Learning Untuk Meningkatkan Penguasaan Konsep Matematika Pada Materi SPLDV Kelas VIII. FIBONACCI: Jurnal Pendidikan Matematika dan Matematika Vol.1 (1), 64-81.

Widyoko, S. E. P. (2013). Evaluasi Program Pembelajaran. Yogyakarta: Pustaka Pelajar.

Yusuf, M., Zulkardi, \& Saleh, T. (2009). Pengembangan soal-soal open ended pada pokok bahasan segitiga dan segiempat di SMP. Jurnal Pendidikan Matematika Vol.3 (2), 48-56.

Caruban: Jurnal Ilmiah Pendidikan Dasar 3(1), 29-39, Januari 2020 DOI: http://dx.doi.org/10.33603/.v3i1.3046, p-ISSN 2615-1391, e-ISSN 2620-3219 CProdi PGSD Universitas Swadaya Gunung Jati 